\title{
What Does China's Rise in Patents Mean? A Look at Quality vs. Quantity
}

Ana Maria Santacreu, Economist

Heting Zhu, Senior Research Associate

W e have previously documented the rise in the number of China's patent applications. These are patents that are filed through a national patent office and the result of innovative activity. ${ }^{1,2}$ In addition to surpassing the United States in terms of application numbers, China has also overtaken other innovation leaders such as Japan, Germany, and South Korea since the midto late-2000s (Figure 1A).

\section{China is quickly catching up with other global leaders in innovation.}

The question that remains is whether this trend indicates that China has become the new global leader in innovation. We argue that policies implemented by the Chinese government that subsidize those who apply for patents would in effect increase the number of applications, and this is likely the driving force of the trends we documented. However, the number of patent applications is an imperfect measure of innovation, as it does not measure the quality of the patent. To assess whether these trends imply that China is becoming an innovation leader, we need to look beyond the number of patents that China files through patent offices and evaluate their quality.

We analyze the following three measures of innovation that control for patent quality. First, patent grants may be more suitable than patent applications in measuring the usefulness or creativity of a nation's inventions because the approval requirements are usually much higher than the application requirements for a patent. Patent grants are a subset of patent applications that experts from the national patent office consider significantly innovative. Second, we categorize patents according to the standards of innovation that are required for a grant. Indeed, Chinese patents are sub-classified into highly innovative "invention" patents and lower-quality "utility model" and "design" patents. ${ }^{3}$ Third, we look at the number of patents applied for abroad
Figure 1

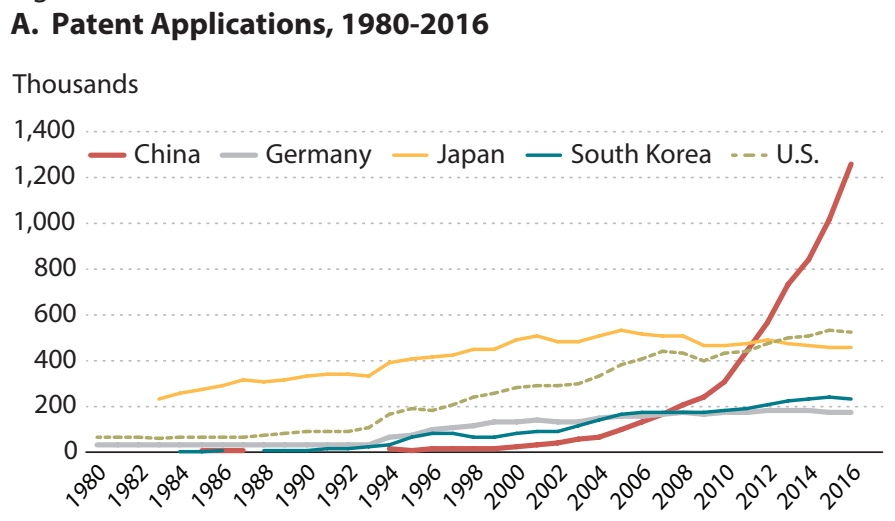

\section{B. Patent Grants, 1980-2016}

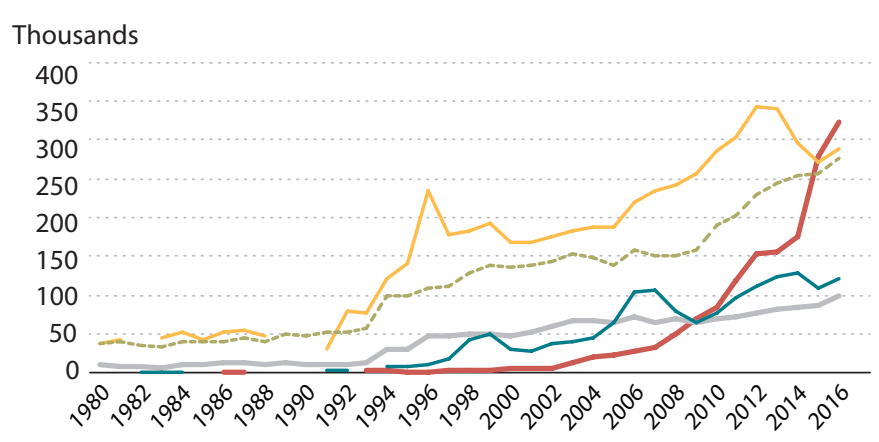

SOURCE: World Intellectual Property Organization.

versus the number of patents applied for domestically. An invention owner would apply for patents abroad to protect intellectual property rights overseas. When imitation risk is high, there is a higher incentive to do this. In what follows, we analyze the evolution of these alternative measures of patent quality for China.

First, the number of patents granted in China began to increase dramatically from the mid-2000s. In 2015 and 2016, it outpaced the numbers in Japan and the United States (Figure 1B). However, the ratio of patents granted to patent applications in China remained the lowest among our sample of countries. Between 2000 and 2016, the average share of patents granted among total applications in 
Figure 2

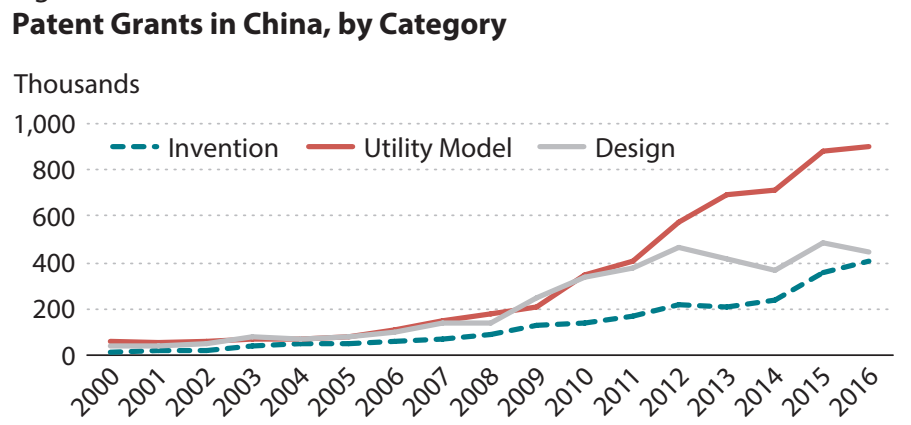

SOURCE: China's State Intellectual Property Office.

China was only 23.44 percent, whereas it was 43.50 percent in Germany, 44.93 percent in the United States, 45.54 percent in South Korea, and 50.50 percent in Japan. Therefore, despite the significant increase in the number of patents granted, China still lags behind other innovative countries in its "success" ratio. One justification could be that China started the process of increasing patent applications later than many other countries, and the evaluation period can be long. Hence, China experienced a delay in the rise of the patent grants to applications ratio. 4

Second, Figure 2 shows the evolution of the three different categories of patent grants (invention, utility model, and design) in China for 2000-16. The figure shows that the largest increase has been in utility model patents, followed by design and then invention patents. During our period of analysis, invention patents accounted for only 19.3 percent of the total number of grants, and utility model and design patents accounted for 44.5 percent and 36.2 percent, respectively. These numbers imply that the actual technological improvement in China is not significant compared with its skyrocketing number of patent applications. Recently implemented government policies that subsidize the number of patent applications may be an explanation for these patterns. Because firms and organizations usually respond well to monetary incentives, a battle between quantity and quality seems inevitable, at least in the short term. ${ }^{5}$

Finally, China also lags behind other innovation leaders with respect to the share of patents that are filed and granted abroad. We focus on the contrast between the United States and China. According to data from the World Intellectual
Property Organization, although China has exceeded the United States in the number of patent applications and patent grants recently, its shares of patents filed or granted abroad are still much lower than those of the United States. Specifically, in 2016, only 4.17 percent of 1.2 million Chinese patent applications were filed overseas, and 6.31 percent of the total patents were granted in foreign countries. Conversely, 43.40 percent of 521,802 U.S. patent applications were filed overseas, and 48.10 percent of the total patents were granted in foreign countries. One explanation could be that the United States has a larger incentive to protect its intellectual properties abroad compared with China. Another explanation could be that many Chinese patent applications could not withstand the international evaluation because of the lower quality of its patents.

Using three measurements of patent quality, we have argued that there is still room for China to improve its innovative activities. Comparing the number of patent applications and patent grants across countries, we see that although the United States and Japan have been global leaders in innovation for a long time, South Korea and China are catching up fast. If China sustains its large innovation investment and shifts its focus from quantity to quality, together with an improvement in intellectual property rights, the likelihood of becoming one of the next innovation leaders could be much higher.

\section{Notes}

1 Santacreu, Ana Maria. "The New World Leader in Innovation." Federal Reserve Bank of St. Louis On the Economy Blog, July 3, 2017; https://www.stlouisfed.org/on-the-economy/2017/july/world-leaders-innovation.

2 Santacreu, Ana Maria and Zhu, Heting. "Has China Overtaken the U.S. in Terms of Innovation?" Federal Reserve Bank of St. Louis On the Economy Blog, March 12, 2018; https://www.stlouisfed.org/on-the-economy/2018/march/ china-overtaken-us-terms-innovation.

3 China Power Team. "Are Patents Indicative of Chinese Innovation?" China Power, February 15, 2016. Updated August 11, 2017; https://chinapower.csis.org/patents/.

${ }^{4}$ It is important to note that the standards to grant a patent differ across patent offices. In this case, if the patent office in China were more willing to grant patents than the patent office in the United States, looking at patent grants would not be indicative of the quality of the patent.

5 China Power Team (2017, see footnote 3). 